\title{
Stimulating the accumulation of deposits in banks to finance the construction industry of the European Union
}

\author{
Igor Anokhov ${ }^{1, *}$ \\ ${ }^{1}$ Baikal State University, 664003, Lenina str., 11, Irkutsk, Russia
}

\begin{abstract}
The paper is devoted to the search for a way of development of the construction industry by the deposits in banks. The analysis of the eurozone statistics has shown that most of the deposits are short-term ones. In addition, loans for the purchase of housing and loans to non-financial corporations are issued mainly for up to one year. This constrains the demand for housing and construction projects, limits the opportunities for long-term crediting construction companies, and also causes Juglar's economic cycles. In this regard, measures are needed to make the financial plans of all stakeholders on the construction market lengthier. The author proposes to create the targeted deposits in banks under collateral in the form of buildings, structures, and infrastructure facilities. This will increase the propensity to save and invest free money in the construction industry.
\end{abstract}

Construction industry has a great economic importance. It strongly influences related industries, because consumes a variety of diverse resources. In construction, a large amount of skilled and unskilled labor is used, so the labor market significantly depends on its activity. In addition, the construction sector is usually limited to the region, so construction companies are less likely inclined competing with foreign companies. For this reason, the development of construction revitalizes primarily the regional economy in contrast to the market of building materials and structures, on which foreign suppliers operate freely.

Therefore, the balanced development of the construction industry is extremely important. This, in turn, requires maintaining the demand for the contractors' services from households and non-financial corporations through lending. Let us consider the data on the structure of loans issued before the crisis in 2007 in the Eurozone (Table 1).

As we see, in the Eurozone households prefer taking loans of up to 1 year with a floating interest rate for the purchase of an expensive long-term facility - a house (51\%). At the same time, households take loans for a period of $1-5$ years (48\%) and over 5 years $(26 \%)$ for consumer purposes. Thus, households for some reason do not readily take large loans for more than 1 year, but at the same time, loans for consumption are taken for a much longer period.

${ }^{*}$ Corresponding author: i.v.anokhov@yandex.ru 
In addition, the Table 1 shows that the larger the country's economy and the better its financial status (for example, Germany, France, Belgium, the Netherlands), the longer the households take loans for the purchase of housing. In countries with problems in public finances (Greece, Spain, Ireland, Italy, and Portugal), the population can afford taking loans for housing only for up to one year.

Table 1. Loans to households by countries and terms (percentage of total; average for the period from January 2003 to May 2006) [1].

\begin{tabular}{|l|c|c|c|c|c|c|c|c|}
\hline & \multicolumn{3}{|c|}{ For the purchase of a house } & \multicolumn{4}{c|}{ For consumer purposes } \\
\cline { 2 - 10 } & $\begin{array}{c}\text { Floating } \\
\text { rates up to } \\
\text { one year }\end{array}$ & $\begin{array}{c}\text { From } \\
\text { one to } \\
\text { five } \\
\text { years }\end{array}$ & $\begin{array}{c}\text { From } \\
\text { five to to } \\
\text { ten years }\end{array}$ & $\begin{array}{c}\text { More } \\
\text { than ten } \\
\text { years }\end{array}$ & $\begin{array}{c}\text { Bank } \\
\text { overdraft }\end{array}$ & $\begin{array}{c}\text { Floating } \\
\text { rates up to } \\
\text { one year }\end{array}$ & $\begin{array}{c}\text { From one } \\
\text { to five } \\
\text { years }\end{array}$ & $\begin{array}{c}\text { More } \\
\text { than } \\
\text { five } \\
\text { years }\end{array}$ \\
\hline Eurozone & 51 & 13 & 18 & 18 & 15 & 26 & 48 & 26 \\
\hline Belgium & 33 & 14 & 15 & 38 & 11 & 8 & 63 & 28 \\
\hline Germany & 17 & 19 & 39 & 25 & 11 & 16 & 49 & 35 \\
\hline Greece & 84 & 7 & 2 & 7 & 53 & 40 & 42 & 18 \\
\hline Spain & 89 & 10 & 1 & 1 & 0 & 50 & 29 & 21 \\
\hline France & 29 & 11 & 11 & 49 & 19 & 10 & 70 & 20 \\
\hline Ireland & 84 & 15 & 0 & 0 & 11 & 51 & 41 & 8 \\
\hline Italy & 82 & 5 & 2 & 11 & 25 & 22 & 53 & 25 \\
\hline Luxembur & 83 & 1 & 1 & 16 & 8 & 12 & 72 & 16 \\
\hline Netherlan & 30 & 19 & 40 & 11 & 22 & 79 & 8 & 13 \\
\hline Austria & 54 & 41 & 1 & 4 & 34 & 84 & 12 & 4 \\
\hline Portugal & 98 & 2 & 1 & 0 & 16 & 62 & 19 & 19 \\
\hline Finland & 94 & 5 & 0 & 0 & 10 & 74 & 26 & 1 \\
\hline
\end{tabular}

Thus, households in the Eurozone cannot create a sustainable and predictable demand for housing because of a very short planning horizon. They are more willing to take loans for consumption for a long period that is associated with a lower loan amount.

A similar picture is seen in the lending to non-financial corporations (Table 2).

Table 2. Loans to non-financial corporations by countries and terms (percentage of total, average for the period from January 2003 to May 2006) [1].

\begin{tabular}{|l|c|c|c|c|c|c|c|}
\hline & \multirow{2}{*}{$\begin{array}{c}\text { Bank } \\
\text { overdraft }\end{array}$} & $\begin{array}{c}\text { Loans up to } 1 \text { million } € \\
\begin{array}{c}\text { Floating rates } \\
\text { up one } \\
\text { year }\end{array}\end{array}$ & $\begin{array}{c}\text { From one } \\
\text { to five } \\
\text { years }\end{array}$ & $\begin{array}{c}\text { More } \\
\text { than five } \\
\text { years }\end{array}$ & $\begin{array}{c}\text { Loans more than } 1 \text { million } € \\
\text { rates up to } \\
\text { one year }\end{array}$ & $\begin{array}{c}\text { From one } \\
\text { to five } \\
\text { years }\end{array}$ & $\begin{array}{c}\text { More } \\
\text { than five } \\
\text { years }\end{array}$ \\
\hline Eurozone & 16 & 27 & 2 & 2 & 60 & 5 & 5 \\
\hline Belgium & 7 & 17 & 2 & 1 & 77 & 3 & 1 \\
\hline Germany & 11 & 12 & 2 & 3 & 65 & 7 & 10 \\
\hline Greece & 34 & 35 & 2 & 0 & 56 & 4 & 2 \\
\hline Spain & 0 & 43 & 2 & 0 & 46 & 6 & 3 \\
\hline France & 15 & 15 & 7 & 8 & 63 & 2 & 5 \\
\hline Ireland & 6 & 20 & 3 & 3 & 57 & 10 & 7 \\
\hline Italy & 32 & 39 & 1 & 1 & 53 & 4 & 3 \\
\hline Luxemburg & 4 & 18 & 0 & 0 & 79 & 1 & 1 \\
\hline Netherlands & 17 & 11 & 6 & 2 & 71 & 3 & 7 \\
\hline Austria & 25 & 19 & 1 & 1 & 75 & 2 & 2 \\
\hline Portugal & 27 & 52 & 1 & 0 & 46 & 1 & 1 \\
\hline
\end{tabular}




\begin{tabular}{|l|l|l|l|l|l|l|l|}
\hline Finland & 4 & 28 & 3 & 0 & 64 & 2 & 2 \\
\hline
\end{tabular}

Judging by the Table 2, non-financial corporations clearly prefer to receive loans for up to one year at floating rates both for up to 1 million $€$ and for more than 1 million $€$. Thus, non-financial corporations tend to plan their financial activities for only one year ahead with subsequent on-lending. For this reason, their demand for construction work is also not predictable.

One of the reasons for this situation can be the policy of banks, which limit the crediting period of households and non-financial corporations. Let us consider the households' deposits in the banks of the Eurozone, which are one of the important sources of resources for crediting the construction sphere (Table 3).

Table 3. Household deposits by countries and terms (percentage of total, average for the period from January 2003 to May 2006) [1].

\begin{tabular}{|l|c|c|c|c|c|c|}
\hline & \multirow{2}{*}{ Overnight } & Redeemable upon notice & \multicolumn{3}{|c|}{ With agreed term } \\
\cline { 3 - 7 } & $\begin{array}{c}\text { Up to three } \\
\text { months }\end{array}$ & $\begin{array}{c}\text { More than } \\
\text { three } \\
\text { months }\end{array}$ & $\begin{array}{c}\text { Up to one } \\
\text { year }\end{array}$ & $\begin{array}{c}\text { From one to } \\
\text { two years }\end{array}$ & $\begin{array}{c}\text { More than } \\
\text { two years }\end{array}$ \\
\hline Eurozone & 35 & 35 & 2 & 12 & 0 & 15 \\
\hline Belgium & 16 & 77 & 0 & 5 & 0 & 1 \\
\hline Germany & 32 & 38 & 7 & 9 & 0 & 14 \\
\hline Greece & 76 & 1 & 1 & 20 & 0 & 2 \\
\hline Spain & 31 & 24 & 0 & 30 & 1 & 14 \\
\hline France & 23 & 42 & 0 & 2 & 0 & 32 \\
\hline Ireland & 46 & 15 & 0 & 26 & 0 & 13 \\
\hline Italy & 79 & 15 & 0 & 6 & 0 & 0 \\
\hline Luxemburg & 42 & 5 & 0 & 50 & 0 & 2 \\
\hline Netherlands & 17 & 75 & 0 & 2 & 0 & 6 \\
\hline Austria & 25 & 0 & 0 & 41 & 5 & 30 \\
\hline Portugal & 31 & 0 & 0 & 63 & 2 & 4 \\
\hline Finland & 61 & 17 & 0 & 18 & 1 & 3 \\
\hline
\end{tabular}

As we see, households are guided by short-term financial planning: the largest share of deposits is limited to a period of up to three months (35\% is overnight loans and 35\% - loans with a notice of up to three months). This, in turn, limits the banks' ability to give long-term loans for the construction and purchase of housing.

Thus, households and non-financial corporations, even in a stable economic situation, prefer to plan their activities for a very short period of time. Meanwhile, such an industry as construction has a lengthy production cycle. Creation of large objects often takes more than 10 years, taking into consideration the design and pre-construction stages. During this period, large financial assets and material values are excluded from circulation. In this case a long cycle of construction of facilities does not correspond to the nature of financial planning and management in households and non-financial corporations, which makes the functioning of the construction industry difficult.

Of course, the financing of the construction industry can also be carried out with the help of the securities market and the financial mechanisms of the state. However, the market of securities is even more unstable than the lending market. In addition, it is focused on shortterm profit and therefore cannot always financially support construction activities. State intervention in the economy has a number of shortcomings: delay in the adoption of decisions, changes in policy, inability to provide and monitor the consequences of the 
decisions made. Thus, the own funds of households and non-financial corporations remain the main source of funds for financing the construction industry.

As a result, the demand for construction activities is unstable and unpredictable. This causes short-term economic cycles of Juglar [2] with a period of 9-11 years. These cycles are entailed by the delay in making investment decisions referring to the launch of new production facilities. Keynes [3] also considered investment expenditures, which are characterized by instability, as the main source of impulses that cause economic fluctuations. As a result, there are shifts in aggregate demand, and, consequently, in the aggregate supply.

Savings and investments are crucial for the economy. At the same time, the ability to save and capitalize is an important acquired quality of a person. It assumes that he has the will to refuse from immediate consumption of free resources, to reduce current consumption to increase future utility and ability to predict future events. From this point of view, four stages of the person's financial planning can be distinguished:

1. Financial planning for a period of up to 1 month. In this case, a person can behave only as a consumer. He clearly prefers spending all his surplus resources and does not consider it necessary to make any financial investments. This situation is typical for a weak development of human intelligence, or for a situation of extreme uncertainty, when no planning is possible (crisis, economic instability, natural disasters, etc.). In this case, the person is concentrated on his own survival and is not inclined to build long-term economic relations and take into account the interests of others. Every economic interaction is difficult, because risks of opportunistic behavior are high. As a consequence, the difficulties of market coordination are replaced by the state coercion.

2. Financial planning for a period of 1 month to 1 year. In this case, the person accumulates experience of interaction with other market participants that allows him making predictions about their behavior. The ability to predict decreases the risks and costs of investing. A person learns to build production chains that require a certain trust between its participants.

3. Financial planning for a period of 1 to 10 years. In this case, a person has a developed sense of empathy that allows him to be aware of the motives of other people's behavior. At the same time, he strives himself to be understood by others and predictable for others. As a result, the economy becomes a network of closely related entities that have a high level of trust in each other. The risks of opportunism and the problem of "a free rider" are minimal. It is advantageous for a person to specialize in a very narrow form of economic activity, transferring all other functions to other network participants.

4. Financial planning for a period of more than 10 years. A person is able to make economic decisions, save and invest knowing well that he personally cannot derive any benefit from this. In other words, he can increase the aggregate future utility for the society at the expense of current utility. In this case, human needs are minimal and determined by the higher values.

Based on the formulated above, the length of the planning horizon and the average period of capital investment correspond to the level of trust in the society and the level of intellectual and ethical development of a person. Measures are needed that will allow this to be achieved in a stable economic situation.

First of all, it is necessary to recognize that households, banks, non-financial organizations and construction companies are parts of the same system. Therefore, the deterioration of the position of one of them immediately worsens the situation of all the others. The ideal situation is that investment in the construction industry will not depend on the phase of the economic cycle. It is possible only if the level of participation of investors will be much higher than in normal banking lending. 
When depositing funds in a bank, households and non-financial organizations cannot know how profitably and reliably their funds are deposited. If they have the information that their deposits in the bank are secured by real buildings, structures and other construction objects, their propensity to save and invest free money can grow significantly.

Securing deposits by buildings, facilities, and infrastructure objects has many advantages: - Their value can last for decades. This distinguishes their reliability from securing loans in the form of securities and the future profit of the borrower. This is especially relevant in times of economic crisis, when the possibilities for reliable investment are minimal;

- One can easily predict their future profitability, which allows making reliable and longterm financial plans;

- Knowledge of their current and future utility stimulates the acquisition of ownership of them (full or partial). As a result, demand for construction company services will be stimulated.

Thus, the emergence of the targeted deposits in banks to lend to the construction industry can mitigate Juglar's economic cycles. As a result, the winners will be the owners of deposits, as well as construction companies, banks, and the state.

\section{References}

1. Differences in MFI interest rates across euro area countries (http://www.ecb.europa.eu/pub/pdf/other/differencesmfiinterestrates2006en.pdf, 2006)

2. C. Juglar, Des crises commercials et de leur retour periodique en France (Paris, 1862)

3. J. M. Keynes, The general theory of employment, interest and money (Macmillan, London, reprinted 2007)

4. A. V. Bogoviz, Y. V. Ragulina, N. V. Sirotkina, Advances in Intelligent Systems and Computing, 622, 597-602 (2018)

5. K. Head, T. Mayer, Review of Economics and Statistics, 86(4) (2004)

6. J. Greenwood, Interest representation in the European Union (Palgrave, London, 2017)

7. M. Y. Veselovsky, M. A. Izmailova, A. V. Bogoviz, S. V. Lobova, Y. V. Ragulina, Quality - Access to Success, 19(163), 30-36 (2018)

8. M. Smol, J. Kulczycka, A. Henclik, K, Gorazda, Z. Wzorek, Journal of Cleaner Production, 95, 45-54 (2015) 